\title{
Research on the Strategies of Tourism activation of Traditlonal Villages: Taking the Village of Shanxi Dongjialing as example
}

\author{
Yongjun Guo ${ }^{1}$, Chong'en Wang ${ }^{2}$ \\ ${ }^{1}$ College of Architecture and Civil Engineering,Taiyuan University of Technology,Taiyuan,Shanxi,030024,China \\ ${ }^{2}$ College of Architecture and Civil Engineering,Taiyuan University of Technology,Taiyuan,Shanxi,030024,China
}

\begin{abstract}
Rural tourism has gradually become an important part of many forms of protection in traditional villages. Through the field research and analysis of existing literature and implemented projects, the main problems existing in traditional village tourism planning are summarized, and then taking the tourism activation of Dongjialing in Shanxi Province as an example, we will explore strategies to solve such problems and provide reference for the protection and utilization of traditional villages in China.
\end{abstract}

\section{Introduction}

Traditional villages need to protect not only their material cultural heritage, but also intangible cultural heritage and a large number of unique historical memories, clan spreads, proverbial dialects, township rules, production methods, all of which are rooted in the former or In the production and living activities of the main body of the villagers who are now living in it, the so-called use and retreat can be used as a village for the development of tourism resources, and it is necessary to consider the live transmission of these elements in the tourism planning. The fundamental way out for village planning and construction is to build a self-consistent mechanism for rural communities to benefit rationally in the continuation of tradition, and to cultivate villagers to become the conscious subject of village protection and utilization. However, in the existing traditional village tourism planning, there is still a widespread problem of avoiding one another, static protection, and ignoring the role of the original villagers.

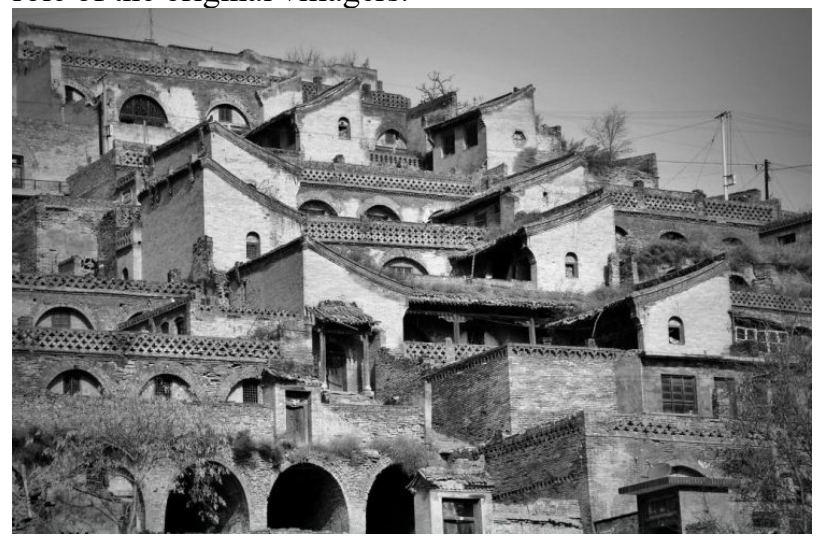

Fig. 1.Village partial landscape
Dongjialing Village is located in Nanguan Town, Lingshi County, Jinzhong City, Shanxi Province. It is 20 kilometers away from Lingshi County in the north, and borders on Huozhou City and Luxi County in the south. It faces the Weihe River in Nanguan Town. Dongjialing Village is the location of the Zhao family, one of the socalled "Lingshi eight small homes". It is rumored that Zhao Jia once worked in Henan and other places, "for the benefit of the rivers and seas, according to the capital." There are 63 courtyards in the Ming and Qing Dynasties. According to the inscription of a courtyard, in the five years of Qing Emperor Qianlong (AD 1740), the village has formed a certain scale. In 2009, Dongjialing was announced as a historical and cultural village in Shanxi Province. In 2013, the second batch of traditional Chinese villages was announced.

\section{Material cultural heritage}

\subsection{Unique landscape pattern}

Dongjialing is located in the southwestern gorge of Nanguan Town. The village is overlooking Lushui and Taiyue Mountain in the east, Luliang Mountain in the west, and the main mountain, case mountain, Qinglong and Baihu in the village are close at hand. The exit is in the southeast of the village, forming the "East Spring Breeze, West". Microclimate conditions to avoid the cold. In the village, the original "Beidou Seven Stars" seven ancient scorpions, the berths, the ancient plaques and the writing towers on the southeast slopes form the central axis of the village, strengthening the spatial connection between the village and the outside. The blending of this settlement with the natural environment fully reflects the traditional concept of adapting to nature and transforming nature.

\section{Village overview}

\footnotetext{
* Corresponding author:1549527889@qq.com
} 


\subsection{Complete defense concept}

The inverted Yuanbao-type foothills where the Dongjialing ancient village is located, the east-west height difference is 15 meters, the north-south height difference is 40 meters, the terrain is undulating, and the village space shifts from the traditional rural layout to the three-dimensional layout. The center of the ancient village is prominent and the axis is clear. The borders composed of steep ridges and fort walls are complete and ingenious. All kinds of buildings are on the mountain. The public spaces such as Longyan and Boike are "sewed together", traditional streets and lanes are intertwined, and various building partitions It is built and fully functional. The village landscape is majestic, showing superb construction techniques and unique functional, defensive and land-saving features.

\subsection{Three-dimensional village layout}

The inverted Yuanbao-type foothills where the Dongjialing ancient village is located, the east-west height difference is 15 meters, the north-south height difference is 40 meters, the terrain is undulating, and the village space shifts from the traditional rural layout to the three-dimensional layout. The center of the ancient village is prominent and the axis is clear. The boundary formed by the steep ridge and the fort wall is complete and ingenious. All kinds of buildings are on the mountain, and the public space such as the dragon raft and the berth is "seeing the needle".

\subsection{TIngenious construction technology}

The existing 63 traditional courtyards in Dongjialing were built during the Ming and Qing Dynasties. The types of residences are flexible and diverse, and the courtyard layout is complete and clear. It is the perfect combination of mountain architecture, raw soil architecture and wood architecture.

Courtyard layout: mainly independent courtyard or quadrangle, consisting of gates, courtyards, wing rooms, and main rooms. The function of the courtyard is distinct, the axis is symmetrical, and the orientation is diverse. The courtyards are stacked up and down, vertically and horizontally to form a complex courtyard group.

Building form: The main room is mostly connected to the kiln. The surface is 3 holes and 5 holes wide, and the depth is $8 \mathrm{~m}$. The holes in each hole are not interconnected. Some caves have wooden porches in front of them, and the columns are 4-5m high. There are two kinds of brick and wood buildings and kiln in the wing room, as well as a combination of kiln and room.

Building decoration: wooden carvings, brick carvings, stone carvings and other decorative methods are widely used in residential buildings. The tile ridges, flower walls and window sills are in various forms and various types. The practice is natural, the mechanism is clear and the human taste is interesting, reflecting the folk psychology, hobbies, beliefs, and customs in the region.

\section{Intangible cultural heritage and others}

Dongjialing's intangible cultural heritage represented by pasta production and folk activities is diverse and interesting. The residential architecture and lifestyle reflect the cultural traditions of local farmers, merchants and Confucianism. As a historical relic of the specific period from the Ming and Qing Dynasties to the Republic of China, Dongjialing dwellings carry a lot of information on politics, economy, culture, customs and construction materials, techniques, techniques, color applications, etc., reflecting the material production in this historical period. Lifestyle, ideas, customs and social customs are precious specimens for studying traditional architectural folklore.

\section{Tourism activation strategy}

\subsection{Heritage protection principle}

Taking the historical and cultural heritage as the core, the tourism product design and development is carried out around historical and cultural resources.

Tourism income should be used for protection according to a certain proportion, to create more jobs for local villagers as much as possible, and to achieve sustainable development of ancient villages.

With the purpose of promoting traditional culture, displaying distinctive features and promoting economic development, it reshapes the simple local features and rich cultural atmosphere of Dongjialing Ancient Village, and builds it into a cultural tourism function with cultural education, historical research, scientific investigation, leisure and other cultural tourism functions. The village has become another core attraction of humanities tourism in Lingshi County and even in Jinzhong District.

\subsection{Concept of tourism activation}

On the basis of respecting and surviving the traditional village texture, tourism activation transforms it into a local experience product with attractive attributes, which makes the interior space of the village form an orderly structure with the resident-visitor interaction as the medium and the external modern space. Reciprocal transactions, and then rebuild the village space production mechanism, guide and cultivate the villagers' society to become the self-sustaining and self-consistent force of the village space.

\subsection{Strategy from static protection to activation heritage}

Tourism transforms the daily life of the villagers into a living process. The villagers gain development opportunities in the plain, self-contained rural life, which also produces the endogenous motivation of selfsustaining traditions, architectural forms, landscape features, folk culture, living habits, etc. The local 
heritage was followed and passed on. In this process, the traditional genes of the village's material, social, and activities are no longer passively in recession and loss. Instead, they are revitalized by the modern power mediated by the tourism flow, so that the village societyproduction mode-material environment is self-owned. The local and gradual linkages operate steadily, realizing the effective balance of traditional villages on modernity and its own orderly evolution.

According to the non-materialist and sustainable design concepts, it can be seen that the above cases lack a holistic grasp of the cultural ecological environment. The protection of cultural and ecological environment is not only to take into account the cultural form of intangible cultural heritage, but also to consider the living conditions, value perspectives of local residents and local social organizations, natural environment, economic system, science and technology and other factors. In particular, it is necessary to pay attention to the living conditions of inhabitants of intangible cultural heritage protected areas. Their living conditions and value perspectives are the decisive factors for the sustainability of intangible culture. Sustainable design points out that a shift towards sustainability will be a complete social system innovation. The sustainable development of the cultural ecological environment also needs to be viewed using this concept. Because with the continuous improvement of means of communication and transportation, the contact and exchange of intangible cultural heritage areas with the outside world will become more and more frequent. We cannot guarantee its closed protection, nor can it expect it to remain in place. Faced with this situation, we need to innovate social systems in response to local characteristics and correctly guide them towards sustainable development.

In the early stage of Dongjialing tourism design, it is necessary to visit the elderly in the village, record the oral history of Dongjialing, collect and organize old photos of the village, relevant cultural and historical materials and intangible cultural heritage, and preserve traditional festival activities.

We need to organize and publish the academic works and brochures of Dongjialing historical and cultural villages, formulate the inheritance mechanism of intangible cultural heritage, announce the inheritors, and publicize the local characteristics; carry out the overall logo design of the village, actively organize various folk activities, and initially carry out cultural tourism activities. Villagers are encouraged to carry out farm tourism.

Construction of Dongjialing Folk Museum and Handicraft Production and Exhibition Center, regular organization of Dongjialing Culture Seminar; establishment of handicraft training classes, inheriting traditional skills; construction of tourism service centers, development of various forms of cultural activities, and promotion of cultural industry diversification.

\subsection{Strategies for attaching importance to the main role of villagers}

Traditional villages are the center of the production and function of the villagers, and the center of life and emotions. They become the abstract and concrete homes of the villagers. The homeland is full of meaning, emotion, experience and social relations. It is a place where the villagers build in the long-term dwelling practice and have a single-person connection.

Non-traditional courtyards on the edge of the ancient village and tourist services such as farmhouses. Conditional residential houses can open family hotels and receive a small number of individual passengers while maintaining the coordination of style. Large and medium-sized tourist reception facilities should be built outside the core protection.

Renovate abandoned courtyards and open up workshops for handicrafts, display and sales. The sale of tourist goods is limited to open attractions such as visitor centers, hand workshops, folk museums, and parking spaces.

The village's Longyan Plaza and the stage will be used to launch traditional experiences, highlighting local characteristics and enhancing visitor participation. When the pavilion was changed to a folk museum, it focused on the social, cultural, economic, and architectural landscapes of Dongjialing Village, showing the people's livelihood in the rise and prosperity, and showing major events in history. Reconstruction of the ancient stage, the renovation of the auditorium and the opening of the cultural courtyard of the village can be as a place for residents' daily cultural activities and a stage for the display of folk activities.

In the newly opened hand workshop, the local specialties of Dongjialing historical and cultural village and its surrounding villages, as well as folk arts and crafts such as paper-cutting and embroidery, were displayed. Sightseeing agricultural parks are opened on the hillsides around the villages to encourage residents to grow fruit-based economic crops and organic vegetables as a display of dryland agricultural planting and farmhouse picking activities. Carry out outdoor activities such as hiking in the countryside and exploring the remains around the legend of the writing tower and Liulang.

The eco-tourism park is based on the development of ecological agriculture, with the aim of creating a beautiful natural environment and producing highquality green agricultural products, and taking the road of forestry viewing and leisure vacation. The organic combination of agriculture and tourism has been fully considered in the selection and design of planting projects. The park planning projects include park selection projects such as picking gardens, fishing ponds, facility agriculture, crop maze, and ecological farming. In the arrangement of leisure activities, the pursuit of interaction with tourists, participatory projects arranged for picking, fishing, etc., is the combination of urban and rural areas, people return to nature, pursue wild interest, taste "live a farmhouse, do a farmer's life, eat a farmer's meal Enjoy the ideal holiday park for a day of fun.

The public's crisis of the decline of the inheritance of intangible culture, therefore, the construction of different levels of public participation platform is the work of the 
government and academia. Designers and design researchers must also recognize that the public is the subject of the inheritance and development of ethical and intangible culture. It is necessary to create an open platform for the public to participate and seek a design policy of "taking the residents themselves as the main people".

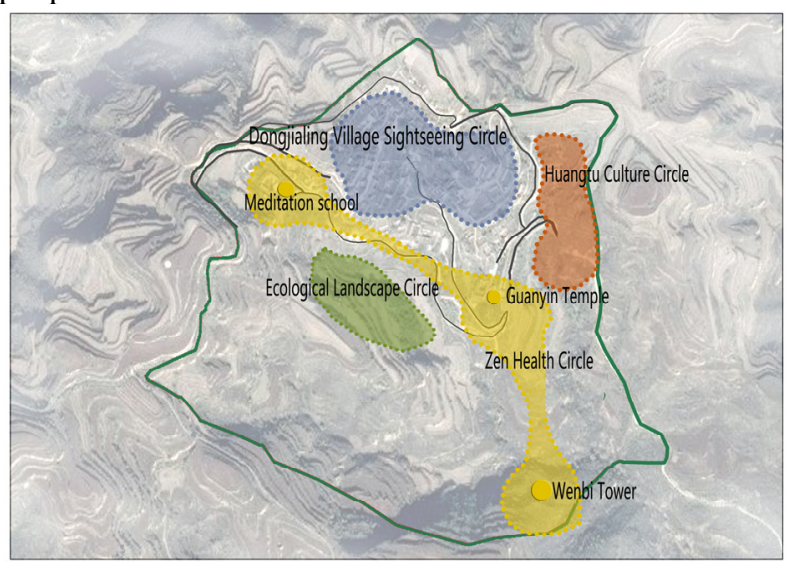

Fig. 2. Tourism planning circle

\subsection{Attach importance to the inclusion of tourism in traditional village reserves}

Treating neighboring and related large and small villages as a whole helps the villagers' mutual support and the inheritance of historical memory and the maintenance of traditional vitality. On the contrary, it is inevitable to "protect" all the villages in isolation, and it will inevitably move towards specimenization and attraction.

The ancient village reserve refers to the protection of some villages (ancient villages) with the same form and humanities in one area. Some of these villages have been included in the list of traditional villages in the country, and some are not included, but they are historical community of homes, often referred to as "ancient villages." Non-community traditional villages are suitable for single-protection, and "old villages" can adopt protected areas. Although each village appears to be an individual, in reality, the historical life between the villages is related to each other. In some areas, often adjacent villages are inextricably linked in the process of creation and development. In the common historical destiny, natural change, ethnic evolution or subordination; sharing the same folk culture in the same climatic conditions, natural environment, ethnic background and lifestyle. For this "old village group", if a single individualized protection is used, it will cut off their historical context and make their humanities become isolated and thin. On the contrary, if these neighboring and related large and small villages are treated as a whole, it will help the mutual support of the village and the inheritance of historical memory and the maintenance of traditional vitality.

Dongjialing Village is located in Taiyuan, the southern end of the Jinshang Folk Customs Tour Line in the center of Jinzhong. It is located in the middle of the Shanxi University Hospital line centered on Jinzhong Jincheng. It can be incorporated into Yuci Old Town,
Changjia Manor, Qiao Family Courtyard Pingyao Ancient City, Wang Family Courtyard Tourism Route, and Changjia Manor, Qiao Family Courtyard, Wang Family Courtyard, Liu Citi Residence, Huangcheng Xiangfu, Li Home compound tour route.

China's non-legacy protection has identified a number of "cultural and ecological protection zones" with good results, avoiding the problem of a single "list protection" separating the non-legacy from its cultural soil. We can imagine that all the villages will be "protected" in isolation from the door, and it will inevitably move toward specimenization and attraction. Of course, not all traditional villages have protected areas. This is conditional. The "old villages" referred to by protected areas must contain two elements: First, there must be traditional villages listed in the national directory, whether one or more, this is the focus. Secondly, there are still some villages around. Although they are not listed, the traditional villages listed in the protection list are interdependent in history and humanities, and the cultural ecology is better. Such an "old village group" is suitable for establishing a protected area.

\section{Acknowledgment}

The authors would like to thank the Soft Science in ShanxiProvince: Research on the Protection and DevelopmentStrategy of Chinese Traditional Villages in Shanxi Provinceunder Urbanization (2017041023-2) for their support in this research.

\section{References}

1. J.Feng. The dilemma and way out of traditional villages[J].Traditional Village 1, 7 (2013)

2. Y.Yang. Sustainable Development of Intangible Culture and Local Design Innovation [D]. Changsha : Hunan University,2008.

3. B.Wu.X.B. Traditional Villages and Tourism Activation: Academic and Legal Analysis[J]. Journal of Yangzhou University21,16 (2017)

4. D.Liu.X.Zhang.D.Yuan. Indiscriminate productive protection and the daily needs of the people[J]. Forum on Chinese Culture3, 120 (2014)

5. K.Yang. Development and Protection of Traditional Villages under the Influence of Tourism[D]. Kunming: Kunming University of Science and Technology, 2016 